\title{
Claudel's The Confessional Letter at the Center of Paul Claudel's L'Échange
}

\author{
M. Kathleen Madigan \\ Rockurst University, Kansas City
}

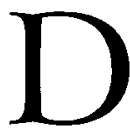

iscussion of whether the second version (composed in 19501951) of Paul Claudel's play L'Échange improved or ruined the first (composed 1893-84 and performed for the first time in 1914) version has focused much on the invention of the two letters at the beginning of act three. These letters from the character Marthe, the first to her parents and the second to her parish priest, replace what had been her monologue and cry for justice in version one. That these letters were intended to play a critical role in Claudel's new play is attested to by the fact that when the theatre director Jean-Louis Barrault preferred to stage the monologue of the first version, Claudel pleaded with him to accept the letters, writing "Faites-moi cette concession auprès de toutes celles que moi-même je vous ai faites" (L'Échange 27o). Claudel added that if Barrault insisted, he could leave out Marthe's first letter to her parents. But in the author's mind, the confession written to the parish priest remained non-negotiable. For these reasons, I would like to explore the nature and function of this particular letter and to offer a perspective on the role it plays in version two, given the essential theme of the play.

But first, let us review the grounds both for the reluctance and the appreciation with which these letters have been received. Barrault was apparently surprised by the introduction of Marthe's writings and felt at first that though they added to the atmosphere, they did not contribute enough to the action of the play. Critics after Barrault have also pointed out that the letters lack the poetic grandeur of the first version, and that Marthe's prosaic monologue sounds comically artificial. ${ }^{1}$ On the other hand, enthusiastic critics depict the new Marthe who asks for pardon in her letter as more mature and generous than the victim who cries out for justice in version one. The new Marthe's language is described as "sensitive" and "expressive". 2 And the reading of the letters is viewed as an effective dramatic technique which reveals Marthe's insight and selfcontrol.3 


\section{Kathleen Madigan}

My intention here is not to stir the flames of an "Anciens" versus the "Modernes" debate or to polarize those who prefer one version to the other. Rather, with all due respect to the recognized poetic beauty of version one, I would like to concentrate here on why I believe that that this letter merits designation as an important transitional if not the pivotal "scene" of the play, without which a thematically coherent resolution would not be possible. For it is in this scene that we follow the interior action of Marthe's heart in her very willingness to exchange her former role for one which incorporates spiritual exchange in lieu of mere justice.

Let us consider Barrault's initial concern that the letters did not provide enough action for the beginning of the third act. It is true that the pace of the play changes suddenly from the passion and tensions of the dialogue between Louis Lane and Lechy Elbernon to the stark solitude and calming action of Marthe reading her letters in Act III. But this new pace signals a dramatic development, as it expresses the interior change of heart which Marthe experiences. In response to Barrault's criticism, Claudel responded "Ne dites pas qu'il n'y a pas d'action! Il y a action, drame comme dans les tragédies classiques, partout où il y a conflit de sentiment, de situations, un "parting of the ways." (Lioure, Correspondance 240) Here the letters give voice to the interior action of Marthe's soul, as she develops from victim to pardon-seeker.

In reading the letter addressed to her parish priest, Marthe ponders all that has taken place and her response to it. Here she demonstrates her reflective nature and allows the audience to understand her thought processes and to experience how she voluntarily decides to participate at the deepest yet most human level in a spiritual exchange for the benefit of herself and others. Admittedly, this type of confession may be unconventional, but it avoids the problem of introducing another character into the play (as well as violating the confessional seal). This voiced confession conveys the interior transition which Marthe makes from unwitting victim to willing benefactor to the spiritual welfare of others. Instead of blaming others, in her confession she reveals her own failings and recognizes that the bond between her and her husband makes it ultimately impossible to demarcate absolutely the boundaries of innocence, transgression or negligence.

While the confessional scene may be viewed in this capacity as essential, in terms of rhythm and location it appears to suggest a setting beyond the classical limits of time and place of the play. Marthe appears under the stars, reading under the light of a storm lamp. In some ways, it 


\section{The Confessional Letter at the Center of L'Échange}

does not matter where she is located when reading the letter: she could be anywhere, for the action which we are witnessing is interior. Likewise, she is taking some time out from the steady pace of dialogue with the other characters. Yet we cannot understand how to interpret her actions in the sequence and setting of the ensuing scenes without the transcendence of this central one.

Let us examine closely this confessional letter. After beginning her act of reconciliation with a traditional formula used to ask for forgiveness. "Pardonnez-moi, mon père, parce que j’ai péché" (L'Échange 219) she initially suggests that she has not sinned, but that she is actually asking for pardon for someone else. It appears at first as though she wants to obtain absolution for Louis: "Quelqu'un l'aura demandée pour lui à sa place" (L'Échange 219). One recalls that Louis told Marthe in Act Two that she had taken his soul and should keep it: "Tu m'as pris mon âme...Garde-la." (L'Échange 208) So she become's soul keeper for Louis. A shift occurs, though, as she examines her own conscience. At first she seems to confront the faults of Louis, but then-realizing that she is as much a part of the experience of her relationship with Louis as he is-she asks whether she herself has not sinned: "Et puis c'est si sûr que que ça que je n'aie pas péché?" (L'Échange 208) The "messy" part about this, as she reveals, is that her conscience cannot be completely separated from that of Louis. That is not to say that she claims responsibility for the weakness of her spouse, but rather she recognizes shared responsibility. After a seemingly casual request for a "carte blanche" absolution for two or three, as she puts it, she quickly shifts the attention back to her own responsibility in the turn her life has taken.

When she speaks of giving Louis the "tartine" which he had asked for, apparently when they met in France, Marthe appears to think of herself as a mother figure, since she was preparing it for children. In response to Marthe's question of whether she was wrong to love him and whether she did not marry him legitimately, Louis responds "Je n'étais qu'un enfant. Mais toi, tu aurais dû savoir et ne pas écouter ainsi ce que je te disais" (L'Échange 189) At least one critic has noted that while Marthe plays the role of the irresponsible woman-child in the first version, the roles are reversed in version two: Marthe becomes the childminder who distributes food to the child (Miguet-Ollagnier 149). Yet in version two Marthe also casts herself in the role of temptress who seduces someone into a state in which he was incapable of living. She claims “C'est moi qui lui ai appris le péché." (L'Échange 220) 


\section{Kathleen Madigan}

While this suggestion may be questionable, in any case, Louis learns that he cannot in fact endure her discerning eye, which makes him feel trapped; for Louis, Marthe is like "une lampe allumée" in the presence of which he would like to hide (L'Échange 168); Claudel calls him "L'homme de la fuite" and explains that he cannot accept being enclosed within the narrow limits of Marthe's sacramental love, and therefore he will flee at the first opportunity (Amrouche 124).

At the same time, however, Louis is aware that he is not needed by Marthe. As Lechy tells her "La vérité est que vous n'avez pas besoin de lui. Il a senti cela, ce garçon. On n'a pas besoin de lui." (L'Échange 228) Louis finds himself in an untenable position, and Marthe recognizes her role in putting him there. Not only has she managed to attract someone incapable of an enduring commitment; she has made him feel that she is sufficient without him. So Louis moves out but not on, because he does not change or mature. Marthe moves on because she releases and pardons him.

If their union makes them one, she reasons, then she can no more completely separate herself from the failure of Louis than he can ultimately hide from her pardon and the mercy she requests for him. Bernard Howells writes that the idea of a "providential economy" becomes more prominent in the second version of L'Échange based on:

notions of mystical exchange or substitutions, of vicarious suffering, whereby the merits of one make up... for the demerits of another within the spiritual stock-market sometimes referred to as the 'Thesaurus Ecclesiae'. (Howells 78)

Claudel himself, as Howells points out, has written that we are the condition of each other's eternal salvation; as in mystical communion, another must be consumed in order to live (Howells 80).

In the realm of animal instinct (that of the bete sauvage) then, the tartine offered by Marthe is sign of enticement leading to entrapment. But in mystical communion it at the same time becomes symbolic of Marthe's spiritual expiation, offering what she has for the well-being of another. The symbolism of this communion is echoed in her last conversation with Louis, when Marthe cries out that she has given him her heart to feed on: "Ne t'ai je pas donné mon coeur à manger, une vraie nourriture/ Comme un fruit où les dents restent enfoncées?" (L'Échange 257) If the souls of Louis and Marthe are connected, the plight of one affects the other. Her confession is a cry not only to save her own soul, but also that 


\section{The Confessional Letter at the Center of L'Échange}

of Louis. In this act of spiritual exchange she remains at least as noble a heroine as in the first version and becomes strengthened to face the rest of the external action as it plays itself out.

Claudel conceived of his plays as "conversation intérieure" (Frizeau 30) and certainly Marthe's confessional letter can be read as an outpouring of her interior state as she wrestles with her soul. It could be argued that this interior action is the most breathtaking and important part of the play, for the Marthe of Version I who demands justice in Version II requests and extends mercy instead of being consumed by her own pain. In Claudel's eyes, this kind of conversion can be viewed as more spectacular action than a miracle healing:

Nous avons vu de grands miracles à Lourdes. Il faudrait que Jammes vous racontât cela. Mais qu'est-ce que tous les miracles à côté de celui de la communion, ou d'une conversion? (Frizeau 60)

Marthe ends her letter by asking for pardon again, because "on a péché ensemble tous les deux" ( L'Échange 22O); translation into English here cannot do the French phrase justice. That one person has sinned is emphasized by a verb in the singular, yet we know that "on" can refer to more than one person, which is emphasized by the words for "together" (ensemble) and "both" (tous les deux). This French expression of a complex spiritual reality is, in its own way, poetic.

Marthe's believes in a spiritual economy, in which her actions and those of Louis cannot ultimately be separated, but the merits of one may make up for the deficits of another. This type of spiritual economy is revealed by Miguet-Ollagnier as emerging at the beginning of Act Three, when Marthe reads her letter:

Dès le début de l'acte III, la certitude de la mort prochaine de Louis mène son épouse à superposer mentalement le poids des corps et la pesée des âmes. Le dogme catholique de la communion des saints et de la réversibilité des mérites la persuade que, sinon sur cette terre, du moins dans une céleste balance, leurs actes à tous deux seront pesés sans qu'on puisse séparer ceux de l'homme et de la femme. (Miguet-Ollagnier 773)

As these notions of exchange of merits or payment of another's spiritual debts become ore prevalent, the theme of spiritual exchange becomes more central to the play and the letters the locus in which it emerges most clearly. It may be remembered that the stage décor instruc- 


\section{Kathleen Madigan}

tions call for Marthe to read her letters under a lamp, the light of which may symbolize truth and wisdom.

The changes in language, character and generic form adopted in version two flow from the increased emphasis given to the theme of spiritual exchange, of which the confessional letter is the focal point. With regard to language, the new Marthe is not simply betrayed by a Judas for money; instead, she recognizes her own failing and her language reflects this humility. Marthe recognizes that she is no more an angel than Louis is a child, and if her language has become more prosaic, it nevertheless reflects more complexity and nuance. Precisely because her current situation appears so absurd to her, she rises to the occasion and manages some humor as well. As Claudel writes to Barrault: "Cette vente de sa femme a quelque chose de si sauvage et de si naif que Marthe quoique profondément blessé ne la prend pas tout à fait au sérieux" (Lioure 235). It is precisely in facing this situation fully and in taking a broader view of it that Marthe displays heroism. This is the strong woman who, according to Michel Lioure, Claudel later preferred, whose virtues included "l'obstination, l'énergie, l'espérance, la bonne humeur" (L'Échange 269). Whereas the Marthe of the first version says "Je suis petite et humble" (L'Échange 88), her humility is already suspect, for in Pascal's words "Qui veut faire l'Ange fait la bête"( Frizeau 63). Instead of blaming others for her destiny, Marthe matures in version two. As Claudel wrote in his journal, "En vieillissant on perd pas mal de ses défauts, ils ne nous servent plus à rien" (Claudel, Journal II 777).

It is because she has become reconciled to others and to her present state that Marthe achieves an inner peace and simpler style in expressing it: "A l'apaisement du coeur correspond la simplicité du style." (Lioure 68) At dusk, the Marthe of the first version salutes night such as it was before Lucifer appeared: "Je te salue, ô Nuit/ Telle que tu étais avant la lumière et avant que Lucifer ne parût!" The Marthe of version two, "dans la paix de sa propre conscience" (Van de Ghinste 82) or with a peaceful conscience, accepts the presence of the night and manages to respond to its beauty, comparing the darkness of the sky and stars to a confessional in a Church with candles: "Le ciel étoilé comme un reposoir avec toutes les bougies allumées, ce n'est pas un confessionnal?" (Folio 218) Though not the lyric poetry of the first version, in my opinion, this is poetry in prose. Marthe's pure heart is able to enjoy creation fully: "Pour jouir pleinement de la création", writes Claudel, "il faut avoir un coeur purifié" (Claudel, Journal II 819). 


\section{The Confessional Letter at the Center of L'Échange}

In this sense, Claudel has further unified the theme of spiritual exchange with other elements of the play. As Lawrence Zillmer writes, in the second version, "Claudel has been able to relate idea, character and language into a homogenous entity" (Zillmer 65). The letter relates to the events of the play, yet has an air of transcendence of time and place, since the act of confession itself expresses hope for reconciliation and final union with the eternal. This eternal and transcendent quality of the scene, at once somewhat removed from the action of the play, yet at the center of the meaning of exchange, lends its own ethereal beauty to version two of the drama. And this is fitting, since for Claudel, nothing is beautiful but the eternal: "Il n'y a de beau que ce qui est éternel" (Claudel, Journal II 788).

Finally, Claudel has used this confessional letter to contribute to the dimension of totality to which he aspired. According to Sergio Villani, this concept of "total drama"is delivered through "a synthesis of different artistic forms as a means of expressing the unity and harmony inherent in diversity or plurality" (Villani 74). Marthe represents the model of one in total harmony with God, and this is expressed in her letter. In version two of $L$ '́change, the theme of the play has been carried both through epistolary form as well as dialogical. When Marthe tells Thomas later that she too owes Louis something and Thomas asks "Tant qu'il sera vivant?", Marthe responds "Après aussi" (Claudel L'Échange 248). Without the letter, it would be difficult to understand that she has this spiritual exchange and more than the present life in mind, the consequences of which cannot be fully seen within the confines of the last scene of the play. Her letter is more of what Lioure calls a "méditation mystique" (Lioure 426) than emotional dialogue or even moral teaching.

This leads me to my conclusion, that the confessional letter plays a central role in integrating language and character through exposing interior action and supporting its religious theme of spiritual exchange. Howells has noted that since for Claudel the human experience is an "indivisible totality", it is "the function of religion to integrate life" (Howells 82), as there is no separation into sacred and profane. The confessional letter in this play, in which Marthe confesses her own faults and finds mercy for Louis as well, raises earth to heaven and allows Marthe to gain a more complete perspective and mature outlook. It neither prevents the coming catastrophes of fire and death, nor makes her perfect. But it allows her to regain inner peace and composure and to continue the dialogue with God and with others. Though I am not focusing on the letter to her parents here, that piece may also be seen to some extent as a move 
toward reconciliation and maturity, in that she admits that perhaps they were not all wrong about Louis.

Conscious or not of theoretical justification for the confessional letter, in the end, Barrault conceded that the letters which he had initially found unacceptable added an important dimension to the play. Expressing admiration for many of Claudel's changes to the first version, including the letters, he wrote:

J'ai le plus grand espoir pour L'Échange. Cocasserie, vie, langage direct, émotion entièrement conservée. La balançoire, le mouchoir sur la tête de Louis, et les "secouades" de Marthe et les lettres sont des inventions superbes. (Lioure 237)

For his part, after all that disagreement, Claudel recorded in his journal a note about the play's opening: "Grand succès de l'échange au Marigny." (Claudel, Journal II 791) In the end, the confessional letter brought about the desired effect of reconciliation, even between Barrault and Claudel. Claudel wrote once about the way by which the soul escapes death for eternity through confession: "Telle la parole de confession en qui notre âme pour l'éternité échappera à la mort" (Claudel, Art Poétique 133). Though it does not deter the destruction at the end of the play, Marthe's epistolary meditation does project a ray of life-bringing hope through her sacrificial act of spiritual exchange, which lends its own special brand of poetry and purity to the second version of the play.

\section{Notes}

1 Harold A. Waters concludes his article "A Propos de la seconde version de L'Échange" with the question: "Mais cette seconde version ne serait-elle pas davantage encore "dépouillée de ce magnifique revêtement de mots" (quote from J. Madaule, Le Drame de Paul Claudel, Paris, 1964, 404 ) qui dans la pièce écrite en 1893 masque parfois certaines intentions, mais l'enrichit d'une telle poésie. Josée Van de Ghinste comments in her book La Recherche de la Justice, p. 92: "L'auteur a tellement bien camouflé sa sagesse sous l'aspect assez prosaïque de Marthe....". Marie Miguet-Ollagnier describes Marthe in the same way: "On est alors déçu de voir une Marthe poète devenir prosaïque et terre à terre dans le nouveau texte" in her article "Le Second Echange: Hélas?", p. 169. 


\section{The Confessional Letter at the Center of L'Échange}

2 As Lawrence H. Zillmer characterizes it in his article "The Dramaturgy of L'Échange (Second Version), p. 65, "The language of Marthe is very sensitive and expressive of her ideas and point of view. In the first version she often uses full blown rhetoric in deeply sensitive situations.... One does not sense this in version two. By this time Claudel has been able to relate idea, character and language into a homgenous entity.

3 Elsie M. Wiedner summarizes in her article "Functions of Drama", p. 44, "Marthe reads aloud two letters revealing her grasp of her situation and her self-mastery. Whether or not this change is a qualitative improvement over the first version is debatable, but it seems an attempt to replace the lyric with the dramatic convention. In sum, the changes in the character of Marthe function dramatically to strengthen her presence as an element in the interchange among the characters that Claudel saw as the structure of this play."

\section{Bibliography}

Amrouche, Jean, ed. Mémoires improvisés. Quarante et un entretiens avec Jean Amrouche. Paris: Gallimard, 1969.

Claudel, Paul. Art Poétique. Paris: Gallimard, 1984.

. Journal II (1933-1955) Vol. II. Eds. François Varillon and Jacques Petit. Paris: Gallimard, 1969.

. L'Échange. Folio: Mercure de France, 1964.

. Mes idées sur le théâtre. Paris: Gallimard, 1966.

Frizeau, Gabriel, ed. Correspondance Paul Claudel-Francis Jammes 1897-1938. 5 e édition. Paris: Galllimard, 1952.

Howells, Bernard. “A Metaphysics of Money: Claudel's Échange (1894 and 1951)" Romance Studies; a journal of the University of Wales. 25 (1995): 6984.

Lioure, Michel, ed. Correspondance Paul Claudel-Jean Louis Barrault. Préface de Jean-Louis Barrault. Cahiers Paul Claudel 10. Paris: Editions Gallimard, 1974.

. L'Esthétique dramatique de Paul Claudel. Paris: Armand Colin, 1971.

. "Le grand air de l'Actrice' ou le théâtre et L'Échange” Claudel Studies 9 (19): 4-16.

Miguet-Ollagnier, Marie. “Le Second Échange: Hélas?” Ecritures Claudéliennes. Actes du Colloque de Besançon 27-28 (Mai 1994): 147-176. 


\section{Kathleen Madigan}

Van de Ghinste, Josée. La Recherche de la justice dans le théâtre de Paul Claudel. Paris: Librairie A.G. Nizet, 1980.

Villani, Sergio. "L'Échange: Claudel's first hymn to 'Totality" Claudel Studies. 18 (1991):

Waters, H.A. "A Propos de la seconde version de l'Échange" La Revue des Lettres Modernes 114-116 (1965): 95-109.

Wiedner, Elsie M. "Functions of Drama in the Revision of Paul Claudel's l'Echange" Claudel Studies. 2.2 (1975): 44-51.

Zillmer, Lawrence H. "The Dramaturgy of L'Échange (Second Version)" Claudel Studies 2 (1975): 59-67. 